\title{
Revolución o muerte: Self-Sacrifice and the Ontology of Cuban Revolution
}

\section{Martin Holbraad}

University College London, UK

ABSTRACT With reference to the experience of the Cuban Revolution, this article addresses what may be called the 'late revolutionary paradox': How can so many people in countries such as Cuba continue to pledge visceral allegiance to their revolution while at the same time expressing deep disaffection with it? My main claim is that the paradox is a product of an undue analytical emphasis on the ideological content of revolutionary discourse, with its mantra-like evocations of 'process', 'change', 'emancipation' and other discursive projections into the future. Seen from the point of view of its form as a socio-political event, I argue, revolution turns on a deeper premise, namely the commitment to self-sacrifice, i.e. the assumption that revolutionary subjects are defined by their potential death in defence of the revolution. The premise of self-sacrifice, I argue, lends revolutionary politics a peculiar ontological foundation that makes it radically different to, broadly, 'liberal' understandings of politics. This difference, I show, dissolves the putative 'paradox' of later revolutionary societies such as Cuba, allowing revolutionary subjects to sustain a sense of revolutionary conviction in the face of the many historical contingencies that would seem otherwise to make such enduring convictions increasingly difficult to sustain.

KEYWORDs Revolution, Cuba, sacrifice, political ontology, state

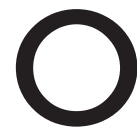
ne of the things that strikes even casual visitors to Cuba since the opening of the island to Western tourism is the startling ease with which local people, particularly in Havana and other parts accustomed to the flow of foreigners since the I99os, voice their many dissatisfactions with the now so obviously ailing state of their socialist Revolution. Complaining about - indeed lamenting - sundry indices of what even the state media sometimes call the 'moral crisis' of recent years is so common among Cuban citizens 
that it has come to acquire the character of a kind of social lubricant, akin to British people's habitual exchanges about the weather (see also Holbraad 20II). The phrase 'no es facil' (it is not easy), which can follow any manner of complaint - from state sanctioned electricity interruptions due to lack of petrol, to interminable programmes of staged political debate on state television, to the rise of delinquency, alcoholism, prostitution and so on - functions almost as a sign of punctuation: a sentence's temporary pause in resigned desperation. 'Life', people say in summary - which is to say life in Cuba's apparently 'late' period of revolutionary socialism - 'is a struggle'. La vida es una lucha. No es facil ... (see also Holgado Fernández 2000; Gordy 2006; Pertierra 20II).

Quickly accustomed to my own friends' daily litanies of this kind in the first months of my $\mathrm{PhD}$ fieldwork in 1998, a time in which the Cuban Revolution's future prospects seemed no less uncertain than they do today, I tended rather quickly to take these as signs of people's basic exhaustion with their government's relentless pursuit of a socialist path since the revolution of 1959 . Indeed, since these complaints were often couched as unfavourable comparisons with the time 'before' (antes) the monumental crisis brought about by the demise of Cuba's economic and military guarantors in the Soviet bloc, which initiated the period Fidel in 1991 pronounced as 'Special' (el periodo especial) and which has never since been officially declared as having ended, my instinct was to interpret my friends' expressions of desperation as an index of the near-collapse of Cuba's enduring, and now so solitary, experiment with socialism. Certainly, Western commentators on Cuban society (CNN, $\mathrm{BBC}$, assorted bloggers, etc.) as well as dissident voices speaking to their foreign publics from the island typically offer just such interpretations: Cubans, oppressed for more than five decades in the name of socialism, are fed up, and, since they cannot say so on pain of punishment by the authorities, they grumble quietly to each other and to any foreigner who may care to listen.

During the course of my fieldwork and in the years since, however, I have come to have serious doubts about this manner of understanding the situation in Cuba. A first inkling that something might be amiss with the liberal democratic fantasy of Cuba finally in popular ferment against an exhausted totalitarian 'regime' came to me one night when, rather unguardedly due to the effects of the rum we were drinking, and a little fed up myself with my closest friends' constant litanies of complaint, I let my own libertarian colours show by suggesting that, if they were so dissatisfied with their situation, they should perhaps do something about changing their government. 'That's what we did in 1973 in Greece' (where I come from), I said in risqué tone. Instantly sobering 
the atmosphere, and cooling it considerably, my good friend Manolo ${ }^{\mathrm{I}}$ (a statetrained playwright in his late 4os) cut my banter off: 'This is not Miami and we are not worms!' (gusanos, the term used popularly and in earlier times officially to refer to the revolution's defectors in the USA and elsewhere). 'This is our country and if we have to fight for it and for all this shit that you see around you, we will!'

It has to be said that at the time I took my friend's seemingly knee-jerk and rather macho reprimand as a natural reaction to a foreigner's presumptions. From a Greek perspective, I am very used to my own chauvinistic responses when it comes to sundry Northern Europeans lecturing me on all of my country's failings - the 'how dare you!' retort. But other poignant episodes that took place as my fieldwork continued showed me that such an interpretation too is inadequate on its own. As I began to realise, my working assumption that people's complaints with the current state of their version of revolutionary socialism must imply a nascent anti-revolutionary impulse was misplaced, and my interlocutors' dissatisfaction came rather from the left, so to speak. If anything, it was often because people were committed to their Revolution that they were so expressly dejected with its ailing state in the Special Period. Indeed, what I found was that Manolo's immediate recourse to the language of violence and self-sacrificial heroism in defence of the Revolution was entirely characteristics of such episodes - so much so that, as I shall argue in this article, ${ }^{2}$ their role deserves to be considered as somehow integral to people's political stance, my question being how. Before setting up the problem, however, let me first show what this heady and intriguingly peculiar mix of late socialist dejection and apparently visceral and chauvinistic revolutionary fervour looks like with reference to two further examples.

The first concerns a conversation I had some months later with another close friend, Hortencia, a middle-aged housewife from one of the poorer neighbourhoods of Havana. The conversation was about her longstanding search for a better flat, which had for years been hampered by the great complexities of moving house in Cuba, due not only to the ailing state of housing stock in recent decades, but above all to the legal prohibition on house sales which means that in order to move home one needs effectively to find someone willing to swap (the system is much more complicated in practice, but I will not enter into the details here). Exasperated with having in the meantime to live with her estranged partner and his parents (a very common predicament in Cuba's arthritic housing situation at the time), Hortencia was recounting the details of her latest failure to secure alternative living quarters. In this 
connection, and in ethnographic mood, I asked her whether an added uncertainty weighing on the process was the lack of clarity in ownership deeds, since so many of the properties people occupy were originally owned by those who left the island at various stages after the revolution - the 'worms' of my earlier example. 'I have no idea,' Hortencia replied, shrugging me off. 'But let them try! [i.e. to claim their properties back in some future date].' 'Don't you know that each and every Cuban is ready to defend themselves? There are plans for these things, there's the armed forces, but we also are all armed. Every house has a weapon, and people are ready!'

If Hortencia's tale of weapons and universal preparedness seemed a little extreme to me at the time, its poignancy was driven home on a separate visit to Havana some years later, in 2004 - my second ethnographic illustration. This took place in the home of another good friend, Rogelio, a music-school-trained brass player who these days earned dollars by teaching foreigners to play Cuban percussion. Gathered in his front room for an informal drinking party with friends, we were chatting about music when another friend of mine, Jose Luis, whom Rogelio had met through me a few times before, arrived quite drunk and in a vile mood. Quite imposing in character, Jose Luis was a Leningrad-trained academic with a keen interest in current affairs. Soon, as was his want when he was drinking, he started to dominate the conversation, on this occasion with a string of comments, in turns bitter and indignant, about all manner of controversies regarding current government policies. Noting that our host Rogelio was getting quietly agitated by this, I tried to steer the conversation onto other topics, but to no avail. At some point Jose Luis indicated the large photographs of Camilo Cienfuegos, Ché Guevara and Fidel himself that Rogelio, like so many other Cubans, kept in prominent positions on his walls. 'Look at these shameless sons of bitches! (descarados hijos de puta) Ok, these two may have been different (pointing at the photos of Camilo and Ché), they're gone. But this guy (Fidel)! What a piece of work he is!' What I had failed to notice at this point is that Rogelio had in the meantime disappeared into his bedroom. As we were all reeling at Jose Luis's outrageous remarks, Rogelio came storming back into the living-room wielding a huge rusty machete, shouting in total paroxysm: 'Get the fuck out! In this house we are revolutionaries, fuuuuuuck!!!! (iiien esta casa somos revolucionarios, coñooooo!!!) and lurched at Jose Luis who beat a quick retreat out onto the street, shouting that the incident would not end there, which, as a matter of fact, it did (the two men never spoke again as far as I know). 
The aim of this article is to account for the fact that, while so often expressing deep discontent and frustration with their current circumstances, so many of the Cuban people I know (though admittedly far from all) continue to support the Revolution, profess their pride for it, and wish to defend it. How is it that the Cuban Revolution can continue to compel the commitment of so many of its citizens notwithstanding - indeed alongside - severe anomie, disillusionment, mass migration, an abiding sense of moral crisis, and the all-round depressed character life in Cuba has acquired in this 'special' post-Soviet era?

Similar questions have frequently been asked in the literature on late socialist societies in general, and a number of anthropologists have sought to address them ethnographically (Humphrey I983; Verdery 1996; Kligman I998; Kharkhordin 1999; Montoya 2007; for Cuba see Rosendahl 1997; Brotherton 2008; Blum 20II). My argument here is offered partly as a response to a tendency in some of this literature to account for the apparently self-contradictory political stances of late socialist subjects by positing what Yurchak has called metaphors of 'binary socialism' (2003, 2006: 6-8). In his landmark historical and ethnographic study of what he calls the 'late socialist' period of the Soviet Union, ${ }^{3}$ Yurchak takes to task analyses that seek to account for these kinds of contradictions by appeal to binary categories such as 'oppression and resistance, repression and freedom, the state and the people [...], public self and private self, truth and lie, reality and dissimulation, morality and corruption, and so on' (2006: 5). Ethnographically, Yurchak suggests,

what tends to get lost in the binary accounts is the crucial and seemingly paradoxical fact that, for a great number of Soviet citizens, many of the fundamental values, ideals and realities of Soviet life [...] were of genuine importance, despite the fact that many of their everyday practices routinely transgressed, reinterpreted, or refused certain norms and rules represented in the official ideology of the socialist state. (2006: 8)

And such an ethnographic distortion, he suggests, is owed also to an analytical prejudice, to the extent that 'binary' accounts of socialist life rely on a series of familiar assumptions about the nature of political subjectivity and agency. Typical also of 'dissident' discourses within the Soviet Union from the r97os onwards, these tend to depict the subjects of 'socialist regimes' - and the language is telling - as unitary individuals whose putative 'split' under socialism is experienced as a loss of authenticity, subjectivity and agency, expressed in an inability to effect change, due to the subjugation of state structures that restrain the citizenry, forcing their acts of resistance into a realm of private truth, and so 
on (Yurchak 2003, 483-4). Precisely the kind of image I also took for granted in my first exposures to daily life and politics in Cuba.

My argument against such binary conceptualisations in what follows accords with Yurchak's critique both ethnographically and theoretically. I too want to show that the visceral character of people's commitment to the revolution and its values deserves to be taken seriously, and that this requires a move away from a series of inappropriate assumptions about what might count as a person in this context. However, my attempt to solve the puzzle of the late revolutionary paradox, if we may call it that, will be different from Yurchak's. Drawing on the Austinian distinction between constative and performative meaning (Austin 1999), Yurchak's core argument is that late Soviet subjects could continue to subscribe to the socialist project because, after Stalin, doing so became principally a matter of performing a series of discursive forms (ways of talking, writing, participating in state structures, etc.) whose constative meaning became more or less opaque and insignificant. Paradoxically, this allowed Soviet citizens to engage in all sorts of activities whose constative meaning might often be rather far from socialist ideals, but whose performance nevertheless conformed to socialist form. By contrast, my attempt to resolve the apparent contradiction of Cubans' simultaneous fervour and depression seeks to widen the gap between the two rather than close it. Borrowing a term from Viveiros de Castro's (2004) analysis of the constitutive role of ontological divergences in social life, I suggest that the apparently self-contradictory stance of Cubans represents, not a binary opposition, but rather a binary 'equivocation'. Cuban people can so viscerally pledge allegiance to their Revolution while also being so fed up with it because the object in either case is different: 'revolution', qua object of allegiance and morbidly depressed discontent respectively, is two different things.

This kind of ontological firewall, I suggest, turns most crucially on the very form of revolutionary action, and particularly its core demand for self-sacrifice the call to heroic preparedness for violence which, as we saw, is the most startling ethnographic corollary of Cuban citizens' enactment of their revolutionary fervour: iRevolucion o Muerte! This demand for self-sacrifice is a catalyst for an act of political cosmogony, if you like, which effectively rescinds the premises upon which political discontent might rely. The chief characteristic of the political universe that the command of self-sacrifice sustains, as I shall show, is its all-encompassing totality - revolution as a world with 'no outside', as Guevara himself once put it. Hence, accounts of the 'paradoxes' of the Cuban revolution which posit a split between reality and propaganda, whereby 'reality' is 
conceived as somehow 'beyond' the 'appearances' that state ideology sets up (hence denying its claims to 'totality'), are in direct contradiction with the content of that ideology - i.e. dismiss it as a matter of analytical pre-disposition.

This kind of distortion is an example of a deeper problem when it comes to the analysis of revolutionary politics, which I venture to call the problem of 'meta-liberalism' or 'analytical liberalism'. In asking 'how can people continue to be revolutionaries in the face of the revolution's many failings?', as I did initially and as commentators on contemporary Cuban politics continue to do, one is basically treating revolution as an ideology that is equivalent to its alternatives (e.g. democracy, oligarchy or whatever) and imagining that people are in some sense free to choose it or not. At stake here, in other words, is the fundamental ontological premise of liberalism, that people have an existence beyond the political forms to which they are subject and their task must be at some level to choose between them - a notion that goes back at least to John Locke's image of peoples choosing their sovereign (Locke 2003). The case of revolutionary politics in Cuba, I want to argue, offers an analytical corrective to this approach inasmuch as it fundamentally recasts the relationship between state and people on which 'meta-liberalism' rests (see also Žižek 1999; Humphrey 2007).

It may be noted that this also implies a methodological corrective of sorts. In particular, it puts into question anthropologists' reflex assumption that the best way to account for people's political commitments is to explore ethnographically how they come to acquire them in particular circumstances. What is it about Cuban history, society, economy (and so on) that makes Cubans adopt or reject the revolution and its ideals, asks the ethnographer, and then proceeds to conduct what can be thought of as a micro-sociology of the social life of political forms - their social reproduction, negotiation and contestation by fleshand-blood people in the socio-historical contingencies that they inhabit. It is remarkable, however, how much this ethnographic reflex owes to the core liberal dispositif of people that remain transcendent to the political forms that they may 'acquire': political life as an Exchange in which ideas, dispositions and practices are adopted, held, contested, resisted or even traded for something else, the job of the ethnographer being to show how this works out on the ground. ${ }^{4}$ So, to the extent revolutionary politics qualifies just this image, it must also hold in check the ethnographic impulse, at least insofar as it conforms to this meta-liberal image. Indeed, the notion that revolutionary politics involves rescinding the liberal distinction between people and the state as an external political form would suggest that the commitment to revolution is, 
precisely, not the kind of thing that can be 'acquired', and therefore the attempt to understand it cannot begin by looking ethnographically at the ways in which, per impossible, it is. Rather than sociological, then, the first question must be ontological: what kind of thing is a revolution, what entities and relations does it bring into play and therefore what form might people's commitment to (or rejection of) it take? Rather than launching into an ethnographic investigation into the ways in which people in Cuba engage with their Revolution, we must inquire first into the ways and senses in which the Revolution itself, as a distinctive political form, dictates its own terms of engagement (cf. Althusser 1971; Foucault I982). In order to answer this question, the bulk of the discussion that follows is devoted to exploring the ontological properties of revolution in Cuba as these enunciate themselves in revolutionary discourse and action - in the ways, then, in which the Revolution enunciates itself as a distinctive political form (see also Holbraad \& Pedersen 20I2, 20I3).

\section{The Political Ontology of Revolution in Cuba}

Cuba offers an optimal vantage point from which to rethink liberal political ontology insofar as the question of how to think the relationship between people and state is arguably what has made it so famous. Even at the most superficial level, one might observe that the extraordinary fascination that the Cuban Revolution has held for generations of sympathisers across the globe has much to do with its projection of an apparently impossible combination of enduring revolutionary fervour with a perduring, against-the-odds statecraft: the bearded images of hope, Fidel's cigar-and-uniform, Ché's youthful martyrdom captured for eternity on T-shirts and beer bottles. Indeed, if the Revolution's vociferous US-based detractors and liberal critics have focused so much energy on puncturing this myth, that only underscores the power of the Cuban Revolution's image as an enduringly 'popular' political experiment which is to say, a revolution belonging, not to a domineering state, but still 'of and for the people'. While it is not my concern here to pass judgement on either side of this cultural and political tussle of imageries, the fact that the Revolution's stance to the conundrum of the state's relationship to the people has been its abiding focus is my empirical point of departure.

While the vast political scientific and historical literature on the Cuban Revolution of course sprawls to include a variety of perspectives and critical stances, it is remarkable that, not only some of its key points of contention and debate, but also the overall historical narrative in which they are embedded, are moulded on the question of the state's relationship with the people, and the 
shifting stances that Cuban revolutionary history exemplifies with reference to it. This narrative's abiding attractor, so to speak, has been the particular conceptualisation of the relationship between people and state that the Cuban revolution has in different periods sought to represent as an alternative, not only to the political order it replaced in 1959 (or to the USA, 'capitalism' and the 'liberal West' more generally), but also to that of previous revolutionary movements, and not least the model of so-called existing socialism exemplified by the USSR. Typified in the figure of (Ernesto) 'Ché' Guevara both as its quasimythical instigator and as its most articulate theorist (alongside Fidel Castro himself), this vision of revolution purports to offer a radical solution to the aforementioned conundrum. In line with earlier Marxist-inspired revolutions, such as the Russian one, the task of revolution is posited, precisely, as that of obviating the very distinction between state and people, such that the two become ontologically coterminous as the state 'withers away' and 'communism' is achieved. What makes the Cuban case in its extreme 'Guevarist' guise distinctive, alongside other socialist projects formulated as an explicit alternative to the USSR such as Maoism, is that this goal is posited, not so much as a transcendent outcome projected into the future (as, for example, in the Leninist vision of a vanguard-led dictatorship of the proletariat leading at some unspecified future to its own dissolution), but more as an immanent function of the process of revolutionary statecraft itself. According to this vision, the immediate gauge for the revolutionary state's legitimacy is the degree to which it promotes a collapse of the distinction between state and people, in a spirit of constant and abiding political experimentation.

The locus classicus of this image of revolution is Che Guevara's 1965 text Socialism and Man in Cuba - in some ways Guevara's equivalent, or even answer, to Lenin's State and Revolution (1992). Written from within the Marxist theoretical tradition in which Guevara had steeped himself as a member of the Cuban government in the early I960s (Kapcia 2000: I2I), the text is presented explicitly as a refutation, based on 'the facts as they exist in Cuba', of the 'common argument from the mouths of capitalist spokesmen [...] that socialism, or the period of building socialism into which we have entered, is characterised by the abolition of the individual for the sake of the state' (Guevara \& Castro 2009: 7). At the heart of his case is a notion of the Cuban revolution as a project of 'simultaneous creation of socialism and communism' (Bengelsdorf 1994: 9I). The vision is pitched explicitly in contrast to Marxist 'scholasticism', and particularly theories of 'pure transition', in which communism is supposed to result from objective 
conditions emanating from the class dynamics of late capitalism and, following revolution, the dictatorship of the proletariat (Guevara \& Castro 2009, I6-19).

On the contrary, argued Guevara, Cuba represented the possibility of speeding up the transition to socialism by supplementing the objective conditions for socialism - only partially met in the historical contingencies of revolutionary Cuba - with an irreducibly subjective component: an ongoing and deliberate effort to transform the subjectivity of the people by forging the so-called new man, which is considered to be the existential outcome of all socialist revolutions. Alongside creating the material conditions for freedom and prosperity through new economic forms and technologies, then, an abiding objective of revolutionary states and their institutions - in political mobilisations, labour arrangements, education, the arts - is to bring about a new 'consciousness' (conciencia) in the individual, as the subject of its history, in an open-ended project of moral development, based on revolutionary values of voluntarism, selflessness and public service (cf. Badiou 2009: 25)

A truly revolutionary politics, then, is one that is deliberately geared towards an erosion of the very distinction between the state and the people and their respective needs. The liberal charge of totalitarianism is 'refuted' inasmuch as the Cuban state's task is not to 'abolish' the individual, but rather to fashion it into a new subjectivity or consciousness that not only embodies the revolutionary ethos, but enacts the very revolutionary condition that the socialist state is charged with bringing about. At stake, then, is not a clash between two contrasting ways of instituting and organising the relationship between a state and a people (liberal, say, versus totalitarian), but rather two alternative ontological positions on what might count as 'state' and 'people' in the first place. Where liberal assumptions premise the two sides of this political equation as (to a degree) mutually independent variables - viz. sovereigns and subjects who retain their respective scopes for autonomy, with different degrees of relativity - Guevara seeks to articulate revolutionary politics in Cuba as a concerted attempt to render them mutually dependent: a 'society in formation', as he writes, 'that will permit a complete identification between the government and the community in its entirety' (Guevara \& Castro 2009: I6, emphases added).

Guevara's notion that revolutionary politics presupposes an immediate ontological identification between sovereign and subjects is most tellingly expressed in his comments on Fidel Castro's relationship with the people. Having extolled Castro's guerrillas as the 'generator of revolutionary consciousness' in the period of armed combat that led to the 'Triumph' of 1959, Guevara is keen to dispel the 
misperception that, once in government, the forms of leadership and government of this socialist revolutionary vanguard might conform to the image of a 'subordination of the individual by the state' (Guevara \& Castro 2009: 8, Io). While 'the state sometimes makes mistakes', falling out of step with the masses, 'the difficult thing to understand for someone not living through the experience of revolution is [the] close dialectical unity [through which] the mass, as an aggregate of individuals, interacts with its leaders' (Guevara \& Castro 2009: IO-II):

In this Fidel is a master. His own special way of fusing himself with the people can be appreciated only by seeing him in action. At the great public mass meetings one can observe something like the dialogue of two tuning forks whose vibrations interact, producing new sounds. Fidel and the mass begin to vibrate together in a dialogue of growing intensity until they reach the climax in an abrupt conclusion crowned by our cry of struggle and victory. (Guevara \& Castro 2009: Io)

Now, the common story told about the impact of Guevara's radical vision upon the course of the Cuban revolution is one of high idealism, borne, as the rg6os unfolded, of a combination of revolutionary fervour and political and administrative inexperience, leading to a bumpy landing in the realities of state administration in the I970s. Certainly, Guevara's account of Fidel's 'fusion' with the people captures much of the effervescence of the early years of the Revolution - what Jean Paul Sartre, impressed in his visit to Cuba in the early i96os, called 'direct democracy' - with overwhelming support for the revolutionary leadership (Bengelsdorf 1994: 66-98; Kapcia 2000: 99-I46, cf. Sartre I96I), massive popular mobilisations in 'revolutionary offensives' such as the literacy campaign of 196I, and, crucially, Guevara's arguments winning the day in the so-called great economic debate of the early ig6os, following which Castro adopted Guevara's view that the economy should be driven by moral rather than material incentives (Kapcia 2000: $132-8$ ).

Equally, for many, Guevara's almost mystical faith in an 'intuitive' union of state and people expresses an at best naïve and worst crass disregard for due democratic process, responsible for the increasingly ineffectual revolutionary governance of the later I96os, the failings that became apparent to all with the emblematic fiasco of the ro,000 tonne harvest of sugarcane in 1970, which Castro's government had set up explicitly as proof of the capacities of Cuba's putative 'new men' in action (Mesa-Lago 1978). According to this common view, Castro's own admission of the failure in 1971, and the subsequent period 
of 'revolutionary consolidation' in the I970s and early I980s, during which the revolution was substantially institutionalised adopting Soviet-style models of bureaucratised governance, is proof positive of the unworkable idealism of Guevara's project of state-people fusion. In contrast to the Guevarist 'vision', the 'reality' of the advent of the Cuban Revolution, at least from the r97os onwards, is then seen as one of increasing concentration of power in the hands of the revolutionary state - and not least those of Fidel Castro himself - at the expense of the people whose will the state is meant 'intuitively' to embody (e.g. see Bengelsdorf i994). ${ }^{5}$

Such analyses certainly capture core aspects of the exercise of power and government in Cuba and comparable state-revolutionary cases. At the same time, however, the very suggestion that the revolutionary government in Cuba has been blind to the need for democratic 'mediation' between the people and the state, as Bengelsdorf puts it (1994: 6), arguably tells us something important about the logic of revolutionary politics understood in its own terms. If the Cuban leadership and its theoretical forefathers Marx, Lenin and Guevara have been so consistently blind to such a need, as Bengelsdorf shows, that is also because, in a crucial and irreducible sense, from its point of view such a need does not exist. In fact, if analyses such as Bengelsdorfs take for granted a version of what we have called the liberal ontology of state versus people (such that even a socialist revolutionary state must be built with an eye to an already given distinction between the two), that is because they fail to take into account the significance the role of revolution itself, not just as an act that precipitates the project of socialist emancipation, but as a constitutive element of that emancipation itself. ${ }^{6}$ In particular, to project the fusion of state and people as a future or ideal goal for revolutionary politics is unduly to focus on the content of state-revolutionary rhetoric - about the content of revolutionary politics as an ongoing project of transition, construction and so on - at the expense of the key assumption on which this rhetoric is premised. Namely, that, from the perspective of revolutionary form itself, the ontological fusion of state and people which revolutionary politics is taken to enact is already achieved.

Seen in this light, I want to argue, what most basically distinguishes revolutions from other kinds of political action is precisely the peculiarly formal character of their ontological stakes or, to put it the other way round, the peculiarly ontological stakes of their form. In particular, whatever ideological content a revolution might profess (and these can be as different as, for instance, the bourgeoisie is to the proletariat), its minimum requirement is that subjects should be prepared to sacrifice themselves for it. To revolt, simply, is to take up arms against 
the prevailing order, and thus to risk one's self - indeed to risk one's life. Akin to war in this sense (Arendt I990: II-58; cf. Kwon 20I3), revolution is the political act whose price is potential death par excellence. ${ }^{7}$ Indeed, this would be a direct corollary of the concept and the promise of a 'New Man' in socialist revolutionary discourse: that, insofar as the state-revolutionary vanguard and the socialist cadre is ready to give up his entire former way of life including the manner in which he as hitherto been a subject and person himself, he must also be ready to die for the revolutionary cause (Cheng 20II). In a basic sense, then, these two seemingly opposite existential revolutionary outcomes - becoming a New Man, or dying for the revolution - come down to same thing: an essentially ascetic, self-transformative readiness to sacrifice what one is in order for the world - or at least society at large - to orchestrate itself in a new way.

The persistent emphasis on death as self-sacrifice, not only during the revolutionary uprisings in Cuba from I953 to 1959, when allegedly 20,000 lives were lost, but also throughout the subsequent 50 years of revolutionary government, has been well documented and discussed (see particularly Valdés 1992; Pérez 2005: 32I-82). Fidel Castro acknowledges the depth and resonance of this ultimate commitment of revolution when, in History Will Absolve Me, he cites the so-called Apostle of the first Cuban revolution (i.e. the war of independence against Spain in the nineteenth century), José Martí, who was himself killed in battle, and has ever since been commemorated as a martyr by successive generations of Cubans:

There is a limit to the mourning over the corpses of the dead, and that is the infinite Love for the homeland and for the glory that can be seen on her bodies, which has no fear, nor is it abated or ever weakened; because the bodies of the martyrs are the most beautiful altar to honour. [In verse:] ...When there is death/ in the grateful arms of the homeland/ Death is ended, the prison is broken:/ With dying, life, finally, begins! (José Martí, cited in Castro 1967: 53, my translation)

Certainly, such romantic invocations of the spectre of death as a means of popular, and not least national, emancipation are common well beyond the Cuban context, and this is consistent with the present argument about the power of revolution in general as a political form founded on the ontological effects of self-sacrifice. Indeed such an argument only reinforces the more specific observation, elaborated in dazzling detail by Pérez (2005) in a book about the particular salience of suicide in Cuban history more broadly, that a commitment to self-sacrifice has been an abiding feature of the constitution 
of political subjectivities in revolutionary Cuba. As Pérez Jr shows in his close account of how both the discourse and the practice of self-sacrifice came to permeate all aspects Cuban society from 1959 all the way to the Special Period, what is most striking about the Cuban case is the way in which notions of self-sacrificial violence are built into the very fabric of everyday life, having been sustained consistently through the decades of the Revolution as a common denominator of otherwise changing political circumstances.

To take just the most obvious example, the trajectory of the word 'death' itself in revolutionary sloganising is telling. In a way that has by now become entirely ritualised - a matter, indeed, of revolutionary 'form' - all public speaking in revolutionary Cuba is given the final punctuation: Patria o muerte: venceremos! ('Homeland or death: we will win!'). And a further indication of the formal weight of the word 'death' in this context is that at different periods of the revolution this has been coupled with a variety of concepts, depending on the historical and ideological circumstances. Before 1959, in the period of 'revolutionary struggle' (la lucha revolucionaria), 'revolution or death' and 'liberty or death' were the standard battle-calls. After 1959, with the revolutionary forces in power, 'homeland or death' becomes the most common. Then from the rg6os onwards, as the Revolution is increasingly brought into line with the Marxist-Leninist ideology under Soviet influence, there is a shift to 'socialism or death'. And finally, as Gropas (2007) has argued, in the postSoviet era of the I990s and 2000 s there has been a marked return to the more nationalist locution 'Homeland or death'. Indeed, as Blum (20II) shows in her remarkable ethnography of Cuban schooling in the Special Period, this principle has from the early ig6os onward remained at the heart of the Guevaran project to create the New Man, particularly through the education system. Albeit formulaically, school-children in Cuba (the so-called pioneros) still greet each day with what is, when it comes down to it, nothing short of a collective (and heroic) death-wish. iPioeneros por el comunismo, seremos como el Ché!, children chant at each morning assembly: Pioneers for Communism, we will be like Ché! (which is also to say, dead).

The distinctive political ontology on which this formal requirement for subjects that are prepared to die is premised is set out with remarkable clarity by Fidel Castro himself, in an infamous speech delivered to an assembly of leading artists and intellectuals in 1961, where he attempts to allay fears that the Revolution would stifle their freedom of expression: 
The revolution [...] should act in such a way that these artists and intellectuals who are not genuine revolutionaries can find a space within the revolution where they can work and create. Even though they are not revolutionary artists and writers, they should have the opportunity and freedom to express their creative spirit within the revolution. In other words: within the revolution everything; against the revolution, nothing. Against the revolution, nothing, because the revolution also has its rights, and the first right of the revolution is the right to exist, and no one can oppose the revolution's right to exist. Inasmuch as the revolution embodies the interests of the people, inasmuch as the revolution symbolizes the interests of the whole nation, no one can justly claim a right to oppose it. [...] This is not some special law or guideline for artists and writers. It is a general principle for all citizens. It is a fundamental principle of the revolution. Counterrevolutionaries $[\ldots]$ have no rights against the revolution, because the revolution has one right: the right to exist, the right to develop, and the right to be victorious. Who can cast doubt on that right, the right of a people who have said: 'Homeland or death! - that is, Revolution or death. (Castro Ruz, from García Luis 2008: 116-7, emphases added)

In essence, then, revolutionary ontology can be said to be founded on a syllogism that, as it were, has death as its major premise. If to be revolutionary is to be prepared to die for the revolution, and death is understood as the paradigmatic and most complete form of self-sacrifice (see also Willerslev 2009), it follows that revolutionary subjectivity takes an entirely encompassed form: no part of the revolutionary subject, so to speak, remains beyond the revolution. It is in this sense, then, that the mantra-like slogan 'Revolution or death', taken seriously as a logical disjunction, implies the notion of revolution as a political form that, strictly speaking and in line with Castro's logic, has no outside - a notion distilled discursively by Guevara himself when he proclaimed in 1965, two years before his own iconically self-sacrificial death, that 'there is no life outside the Revolution' (Guevara, cited in Pérez 2005: 349). On such a view, the act of armed revolution against the reining powers effectively takes the role of a primordial act of political cosmogony, as it were. The people take arms, not just to usurp state power, but, through the self-sacrificial logic of revolution, to render themselves ontological coterminous with it, thus giving birth, effectively, to a new political universe.

\section{Conclusion: Self-sacrifice and Self-equivocation}

The idea that sacrifice might have ontological, even cosmogonic effects, acting to transform the world at large as well as the people who perform it, is something of an anthropological commonplace (de Heusch 1985). In fact, as 
the editors of this Special Issue suggest in their Introduction, the core idea that otherwise divergent and often critical discussions of the idea of sacrifice in anthropology leave in fact is that 'something (or someone) new can be created through the irreversible giving up of something else, most prominently, a life' (Mayblin \& Course 2013). And the suggestion that the ontological stakes of acts of sacrifice might also be political, such that the 'something or someone' they engender is a new political formation and its corollary form of political subjectivity, is hardly new either. Such ideas have of course been articulated at length by political theorists from Plato to Foucault - indeed, understood as an ascetic stance of self-discipline, the notion of self-sacrifice can be seen as the core theme that cuts across Foucault's oeuvre in particular, from his early analyses of the subject-effects of technologies of domination (Foucault 1977) to his later concern with technologies of the self (Foucault 1998). More strictly within social anthropology, Bloch (199I) has influentially argued that self-sacrificial violence, whether literal or symbolic, is a key feature of the reproduction of political orders, inasmuch as it allows transcendent political forms to be asserted at the expense of the ever-transient lives of the individuals that may man them at any given time. ${ }^{8}$

As indicated in my introduction, this article seeks to add to such lines of argument a consideration of the ways in which the ontological properties of political forms (in this case of revolutionary politics, premised on self-sacrifice) condition the ways and senses in which people may adopt them - the 'terms of engagement' of political life. With reference to the Cuban Revolution, I have argued that the premise of self-sacrifice (and indeed that of terror and violence towards counter-revolutionaries) allows revolutionary politics to enunciate a radical reversal of the very premise of what 'politics' is from a liberal point of view, i.e. a reversal of the idea that people exist independently of the political forms to which they are subject. Revolution is the move of saying that political forms gain priority over the subjects that instantiate them. To go beyond revolution is to die or not even to be human - indeed, to be de-ontologised or at least de-humanised, as the pervasive designation of counter-revolutionaries as 'worms' so chillingly shows. In this sense, strictly and ontologically speaking, a revolution is not the kind of thing that can be 'opposed', 'questioned' or 'replaced', since formally it admits of no 'outside' position from which such a stance could be taken.

This total quality of revolutionary politics, I suggest, effectively serves to dissolve what I started off by calling the 'late revolutionary paradox' - a nation complaining about the state of its Revolution while at the same time pledging 
viscerally its allegiance to it. From a meta-liberal point of view, the position is indeed contradictory: either the professed revolutionary fervour is not as heartfelt as it seems, or the daily litanies of complaint are merely superficial (or, at any rate, Cuban people who exemplify this contradiction are internally divided to the point of schizophrenia). By contrast, taking the total form of revolutionary politics seriously presents us with a different image altogether. In particular, Cuban people's increasing disaffection with the Revolution in this context can be parsed, ontologically speaking, in one of the two ways.

On the one hand people's opposition can be understood as being expressed from a position within the political universe of the revolution, such that to criticise the revolution effectively becomes a revolutionary act in itself. In fact, this has been a prime way in which the government has sought not just to accommodate, but in many instances actively to encourage, and even itself adopt, critical positions with regard to the revolutionary project: by allowing logical space for them to feature as self-criticisms, and in that sense to be understood also as yet another expression of self-sacrifice. Fidel's emphasis on artists' and intellectuals' freedom of expression within the revolution in his famous 196r speech cited above can be understood as a deliberate delineation of such a space (see also Castro Ruz 1977). Certainly, artists and intellectuals have made full use of this kind of opening to 'internal' criticism as a constitutively revolutionary stance - most famously in the films of Thomas Gutierrez Alea from the I96os onwards (Chanan 1985) and more recently in Leonardo Padura's marvellously ethnographic detective novels (Padura Fuentes 200I).

The notion that criticism is inherent to revolutionary commitment, however, has a wider purchase in Cuban society, as illustrated by my opening account of the fracas between Jorge Louis, the drunken academic, and his indignant (eventually machete-wielding) host Rogelio. While Rogelio may have found Jose Luis's disrespectful comments against Fidel Castro politically appalling to the point of counter-revolutionary, the latter, even in his drunken state, tellingly framed his tirade within an expression of respect towards the Revolution's two archetypal martyrs, Ché and Camilo. While disparaging the current state of the revolution, he made a point of conceding, by way of his deference to the martyrs, that its original ideals are to be upheld. Whether sober or drunk, in fact, Jose Luis would often (and, in my estimation, sincerely) profess to be 'a revolutionary', much as Rogelio had done on that difficult evening.

On the other hand, revolutionary totality notwithstanding, people's exasperated criticisms of the revolution could indeed be conceived as being offered from beyond its confines. Liberal indignation with the 'totalitarianism' of 
revolutionary 'regimes' (i.e. the kind of BBC-take with which I started off) is itself proof positive that this is perfectly possible, practically as well as logically. But the kind of revolutionary dejection Cubans themselves have been experiencing with the gradual but seemingly ineluctable erosion of their model of socialism during the Special Period of the r 990 os and 2000 s may also lend itself to this interpretation. Certainly, it would be difficult to maintain that Cubans today live in a closed world (if, in fact, ever they did). The opening to Western tourism in the I990s, massive migration to the USA, Europe and Latin America, Raul Castro's on-going liberalising economic reforms, and the nigh uncontrolled influx of Western ('capitalist') images and sounds through the media are all obvious grounds for doubting whether the 'no-outside' logic of revolutionary discourse has had much real purchase on Cuban society in recent years. Indeed, listening to people's daily expressions of disaffection in Cuba today, one gets the sense of a people conscious of the tragic contingency of their Revolution and well aware of a whole universe lying beyond it - alas beyond the national shores, 'over there' (alla), as Cubans say. Certainly, such an impression is born out over and again in ethnographies of contemporary Cuban society (e.g. see Berg 2004; Holbraad 2004; Hearn 2008; Routon 2010; Blum 20II; Pertierra 20II).

The point is, however, that as far as revolutionary discourse itself is concerned this kind of liberal relativisation of the Revolution - comparing it to an outside and finding it wanting - is fundamentally incoherent, as we have seen. To think of the Revolution in this way is simply to misunderstand what kind of thing a revolution is to itself. We have, then, a case of what Viveiros de Castro calls 'homonymy' (2004: 7): people using the word (or thinking) 'revolution' to refer to (or imagine) something other than what revolutionary discourse itself designates as such. Same word, different concepts. Interestingly, however, while Viveiros de Castro develops the notion of homonymy in order to parse problems of cross-cultural translation (e.g. what counts as an animal for an Amazonian hunter and for an Amazonianist anthropologist may be two different things), the terrain of homonymy here is not just intra-cultural (e.g. Cuban government versus Cuban people), but even intra-personal, as my opening ethnographic examples illustrated. Certainly, the idea of homonymy allows us to conceptualise the otherwise blatant ethnographic observation that people can hold at the same time views that are so divergent as to verge on self-contradiction, which is vividly illustrated by Cubans' complex attitudes to their Revolution. But rather than accept the charge of self-contradiction and then seek to explain it away with reference to the external (historical, social, economic, etc.) circumstances that may account for it, the idea of homonymy 
dissolves the contradiction altogether. In at once detesting and pledging allegiance to their Revolution, according to this analysis, Cubans are not so much speaking against themselves as speaking past themselves: revolution qua object of discontent and revolution qua cause of self-sacrifice are just two different things. To think that they contradict each other is to misunderstand what is at stake in either case. Such a misunderstanding, as we have seen, can play itself out as much within people in Cuba as between them and the metaliberal commentators who find them so contradictory.

However, what perhaps most recommends the dissolution of the late revolutionary paradox as an instance of self-equivocation (to recall Viveiros de Castro's evocative term for the constitutive misunderstandings that ontological divergences generate) is the way it makes sense of the most striking aspect of revolutionary fervour in Cuba, namely the sheer fact that is still there, after all these years of national dejection and complaint. As we have seen, this is partly a matter of the revolution's constitutive immunity to (outside) opposition - this being the crux of the ontological argument from self-equivocation: the object of everyday discontent is by definition something other than what the revolution takes itself to be, so criticism and dejection, however incessant and growing, leaves the revolution proper (i.e. the revolution that demands the people's loyalty) strictly speaking untouched.

This ontological argument for the revolution's immunity to opposition is considerably fortified, however, by an important asymmetry between the concepts of revolution enunciated on either side of our apparent paradox. Qua object of opposition, the revolution is enunciated above all in discourse: lament, complaint, indignation, sense of crisis, and so on. By contrast, as we saw, revolution as an object of total devotion is constituted above all through its own enaction, namely in the people's commitment to self-sacrifice. It is just for this reason that revolution posits itself as immune to all the bad things people might have to say about it: revolution, at base, is a matter not of words but of deeds. For as long as the commitment to the deed of self-sacrificial violence remains in place, according to this logic, discourses of critique and complaint will continue to talk past their object.

To give a sense, not only of the shape that such self-equivocations take ethnographically, but also of the salient role that the commitment to violent selfsacrifice plays in sustaining them, I close with the comments I was given on the topic by a Cuban woman in her mid 3os, speaking in her home in London, where she had been living for few years earlier as a migrant. The words are poignant precisely because they are self-consciously offered from 
the 'outside'. Yet in them something of the self-sacrificial spirit of the Revolution remains:

I was sitting by the window in the kitchen doing my nails and, something about the light, it reminded me of when I was a kid, in the escuelas de campo [the mass mobilization of school-children for voluntary agricultural work in the country-side which is still a regular part of high school education in self-sacrifice (see Blum 20II)]. How hard it was, how I didn't like being there and the only point was to steal some tomatoes or whatever for my mother, and how I still felt I had to stick it out for 30 days, otherwise I'd be weak, and how now all that has lost its meaning. Stick it out for what - it's all gone to shit. [Q: you mean the revolution?]. Yes, the revolution, nothing's left ... I don't know, things have changed so much. Even Arsenio [her step-father], he used never to permit any 'wormery' (gusaneria) inside the house. We always used to tease him - any problem he had he used to write letters to the delegate, get up at $6 \mathrm{am}$ to go to the local government and complain about this or that. My mother now won't let him - 'I'll split your head open if you start with all that crap.' He's understood that no-one lifts a finger anymore - it's all the same to them, and it's hard for Arsenio who really believes in this. [...] He used to say that everything he had he owed to the revolution, his job, the education, the healthcare. But now I'm abroad and with the situation the way it is, he knows that this is all gone and that without what I can help with they'd be in deep trouble. So he stays silent. But yes, the Cuban is revolutionary (el cubano es revolucionario), and it goes a long way back, to the Mambises [the independence fighters of the $19^{\text {th }}$ century]. You know how here [in Europe] if you're a woman and some man starts messing with you in the bus no-one does anything. The Cuban doesn't understand that - he'll fight, he's a fighter (luchador). Fighting is in our blood - the Cuban is a warrior. [Q: And that makes him revolutionary]. Yes, that's what's left of the revolution - it's like my brother, you don't mess with my brother, right?

This, then, is what revolutionary commitment looks like when stripped down to its bare logical essentials: the bare life of violence, enough on its own to subsume life - people's lives, such as that of my interlocutor's brother - to the service of revolution as a total and totalising political universe.

\section{Notes}

I. All personal names and some identifying details are fictitious.

2. Drawing on ethnographic fieldwork in Cuba over the past 15 years, this article is based also on research conducted during a Visiting Scholarship in 2009 at the Centre for Advanced Security Theory (CAST) of the University of Copenhagen. I am grateful to my colleagues at CAST, Mats Fridlund, Noel Parker, Karen Pedesrsen and Lise Philipsen for their guidance in the political science literature, as well as to Ole Wæver, the Centre's Director, and Jytte Bertelsen, the Centre's administrator, 
for hosting me. I am also grateful to Magnus Course and Maya Mayblin for inviting me to participate in this project on sacrifice. Drafts of the article have been read by Stephan Feuchtwang, Caroline Humphrey and Morten Pedersen - their comments and suggestions have been invaluable.

3. This includes the whole period after Stalin, until the rapid demise of the socialist edifice at the end of Perestroika.

4. Appeals to 'flesh', 'blood' and 'ground' connote an image in which social realities invariably feature as 'messier' than the putatively idealised versions of politics presented by ethnographically deprived political scientists and theorists.

5. It should be noted, however, that Guevara's ideas have remained a leitmotif throughout the course of the Revolution, having been reaffirmed in the process of revolutionary 'rectification' in which Castro engaged in the mid-rg8os, to correct some of the excesses of the bureaucratisation of the 1970s, as well as more recently, in the 200os, with initiatives directed at the ideological renewal of the revolution in the face of the post-Soviet 'moral crisis' - see Kapcia (2005), cf. Holbraad (20II).

6. On the role of law and legal theory as a constitutive dimension of this process of revolutionary transformation in Cuba, see Evenson (2003).

7. As the Russian conspirator Nechaev (an associate of Mikhail Bakunin and a self-proclaimed revolutionary) put it in the rather beautifully terse first line of his Catechism of the Revolutionary, 'The revolutionary is a doomed man' (2004[1869]: 71).

8. Note that, as a solution to the core Durkheimian problem of social reproduction, Bloch's argument on the sacrificial structure of the reproduction of political forms itself serves to reproduce the form of meta-liberalism: transient individuals are posited as ontologically distinct from the transcendent political forms that outlive them. The question of how to apportion the balance between individuals and society in anthropological analysis is analogous to the question of how to strike a balance between subjects and sovereigns in liberal political theory.

\section{References}

Althusser, Louis. 1971. Lenin and Philosophy and Other Essays. Translated by Ben Brewster.

New York and London: Monthly Review Press.

Arendt, Hannah. 1990. On Revolution. London: Penguin Books.

Austin, John. 1999. How to Do Things with Words. Oxford: Clarendon Press.

Badiou, Alain. 2009. Logics of Worlds: Being and Event II. Translated by Alberto Toscano.

New York: Continuum.

Bengelsdorf, Carollee. 1994. The Problem of Democracy in Cuba: Between Vision and Reality. New York: Oxford University Press.

Berg, Mette. 2004. Tourism and the Revolutionary New Man: The Specter of Jineterismo in Late 'Special Period' Cuba. Focaal - European Journal of Anthropology, 43:46-56.

Bloch, Maurice. 1991. Prey Into Hunter: The Politics of Religious Experience. Cambridge: Cambridge University Press.

Blum, Denise F. 20Ir. Cuban Youth and Revolutionary Values: Educating the Nerw Socialist Citizen. Austin: University of Texas Press.

Brotherton, P. Sean. 2008. "We Have to Think Like Capitalists but Continue Being Socialists": Medicalized Subjectivities, Emergent Capital, and Socialist Entrepreneurs in Post-Soviet Cuba. American Ethnologist, 35(2):259-74. 
Castro Ruz, Fidel. 1967. La Historia me Absolverá. La Habana: Ediciones Políticas.

-. 1977. Poltica cultural de la Revolución cubana: documentos. La Habana: Eddiciones Ciencias Sociales.

Chanan, Michael. 1985. The Cuban Image: Cinema and Cultural Politics in Cuba. London: British Film Institute.

Cheng, Yinghong. 20Ir. Creating the Nerw Man': From Enlightenment Ideals to Socialist Realities. Honolulu: University of Hawai'i Press.

Evenson, Debra. 2003. Law and Society in Contemporary Cuba. 2nd ed. The Hague: Kluwer Law International.

Foucault, Michel. 1977. Discipline and Punish: The Birth of the Prison. Translated by Alan Sheridan. New York: Random House.

Foucault, Michel. 1982. The Subject and Power. In Michel Foucault: Beyond Structuralism and Hermeneutics, edited by Hubert L. Dreyfus \& Paul Rabinow. pp. 208-228. Chicago: University of Chicago Press.

-. 1998. Ethics: Subjectivity and Truth (Essential Works of Michel Foucault, 1954-1984), edited by Paul Rabinow. London: Allen Lane.

García Luis, Julio. (ed.). 2008. Cuban Revolution Reader: A Documentary History of Fidel Castro's Revolution. Melbourne: Ocean Press.

Gordy, Catherine. 2006. "Sales + Economy + Efficiency = Revolution": Dollarization, Consumer Capitalism, and Popular Responses in Special Period Cuba. Public Culture, I8(2):383-4I2.

Gropas, Maria. 2007. The Repatriotization of Revolutionary Ideology and Mnemonic Landscape in Present Day Havana. Current Anthropology, 48(4):53I-49.

Guevara, Ernesto \& Fidel Castro. 2009. Socialism and Man in Cuba. New York: Pathfinder Press.

Hearn, Adrian H. 2008. Cuba: Religion, Social Capital, and Development. Durham and London: Duke University Press.

de Heusch, Luc. 1985. Sacrifice in Africa: A Structuralist Approach. Manchester: Manchester University Press.

Holbraad, Martin. 2004. Religious "Speculation": The Rise of Ifá Cults and Consumption in Post-Soviet Havana. Journal of Latin American Studies, 36(4):I-2I.

—. 2orr. Dinheiro e necessidades no 'period Especial' de Havana. In Outras Ilhas: Espaços, Temporalidades e Transformações em Cuba, edited by Olivia Maria Gomez da Cunha. pp. 367-94. Rio de Janeiro: Aeroplano Etitora.

Holbraad, Martin \& Morten A. Pedersen. 2012. Revolutionary Securitization: An Anthropological Extension of Securitization Theory. International Theory, 4(2):165-97.

- 2013. Times of Security: Ethnographies of Fear, Protest and the Future. New York and London: Routledge.

Holgado Fernández, Isabel. 200o. iNo es facil! Mujeres cubanas y la crisis revolucionaria. Barcelona: Icaria.

Humphrey, Caroline. 1983. Karl Marx Collective: Economy, Society and Religion in a Siberian Collective Farm. Cambridge: Cambridge University Press.

- 2007. Alternative Freedoms. Proceedings of the American Philosophical Society, I5I(I):I-IO.

Kapcia, Antoni. 2000. Cuba: Island of Dreams. Oxford: Berg.

- 2005. Educational Revolution and Revolutionary Morality in Cuba: The "New Man", Youth and the New "Battle of Ideas". Journal of Moral Education, 34(4):399-4I2. 
Kharkhordin, Oleg. 1999. The Collective and the Individual in Russia: A Study of Practices. Berkeley: University of California Press.

Kligman, Gail. 1998. The Politics of Duplicity: Controlling Reproduction in Ceausescu's Romania. Berkeley: University of California Press.

Kwon, Heonik. 20I3. Time Consciousness in North Korea's State Security Discourse. In Times of Security: Ethnographies of Fear, Protest and the Future, edited by M. Holbraad \& M.A. Pedersen. pp. 198-212. New York and London: Routledge.

Locke, John. 2003. Two Treatises of Government and A Letter Concerning Toleration, edited by Ian Shapiro. New Haven, CT: Yale University Press.

Lenin, Vladimir I. 1992. The State and Revolution. London: Penguin Books.

Mayblin, Maya \& Magnus Course. 2013. The Other Side of Sacrifice. Ethnos, doi: ro.Io8o/ ooI 14844.2013 .841720$.

Mesa-Lago, Carmelo. 1978. Cuba in the 1970s: Pragmatism and Institutionalization. 2nd ed. Albuquerque: University of New Mexico Press.

Montoya, Rosario. 2007. Socialist Scenarios, Power, and State Formation in Sandinista Nicaragua. American Ethnologist, 34(I):71-90.

Padura Fuentes, Leonardo. 200I. Living and Creating in Cuba: Risks and Challenges. In Culture and the Cuban Revolution: Conversations in Havana, edited by John M. Kirk, Leonardo Padura Fuentes. pp. I77-86. Gainesville: University Press of Florida.

Pérez, Jr., Louis A. 2005. To Die in Cuba: Suicide and Society. Chapel Hill: The University of North Carolina Press.

Pertierra, Anna Cristina. 20Ir. Cuba: The Struggle for Consumption. Coconut Creek, FL: Caribbean Studies Press.

Rosendahl, Mona. 1997. Inside the Revolution: Everyday Life in Socialist Cuba. Ithaca, NY: Cornell University Press.

Routon, Kenneth. 20Io. Hidden Powers of the State in the Cuban Imagination. Gainsville: University Press of Florida.

Sartre, Jean-Paul. 196r. Sartre on Cuba. New York: Ballantine Books.

Valdés, Nelson P. 1992. Cuban Political Culture: Between Betrayal and Death. In Cuba in Transition: Crisis and Transformation, edited by S. Halebsky \& J. M. Kirk. pp. 207-28. Boulder, CO: Westview Press.

Verdery, Katherine. 1996. What Was Socialism and What Comes Next? Princeton, NJ: Princeton University Press.

Viveiros de Castro, Eduardo. 2004. Perspectival Anthropology and the Method of Controlled Equivocation. Tipiti, 2(I):3-22.

Willerslev, Rane. 2009. The Optimal Sacrifice: A Study of Voluntary Death among the Siberian Chukchi. American Ethnologist, 36(4):693-704.

Yurchak, Alexei. 2003. The Soviet Hegemony of Form: Everything Was Forever, Until It Was No More. Comparative Studies in Society and History, 45(3):480-510.

- 2006. Everything Was Forever, Until It Was No More: The Last Soviet Generation. Princeton, NJ: Princeton University Press.

Žižek, Slavoj. I999. When the Party Commits Suicide. The Human Rights Project. http://www.egs.edu/faculty/slavoj-zizek/articles/when-the-party-commitssuicide/ (accessed 5 February 20II).

ETHNOS, VOL. 79:3, 2014 (PP. 365-387) 